\title{
KONFERENCE ICOLLE SE LETOS ZAMĚŘILA NA ROLI ODBORNÉHO VZDĚLÁVÁNÍ
}

Jak se mění obsah a průběh odborného vzdělávání vlivem sociálních změn v současné společnosti, jak se vlivem demografického vývoje mění počty studentů nebo jak se $\mathrm{v}$ čase mění požadavky na kompetence $\mathrm{v}$ profesním životě. To jsou jen některá z řady témat, kterým se věnoval letošní 13. ročník mezinárodní vědecké konference ICOLLE 2020. Konferenci uspořádal Institut celoživotního vzdělávání MENDELU ve středu 9. září 2020 pod záštitou rektorky Mendelovy univerzity v Brně a hejtmana Jihomoravského kraje.

$\mathrm{Na}$ letošním ročníku konference se $\mathrm{v}$ Brně setkalo téměř šest desítek odborníků, a to zejména z České republiky. Na osobní účast měl vliv především aktuální stav epidemiologické situace, kvưli němuž například zahraniční hosté z Mad'arska a Polska přednesli své př́spěvky formou videokonference.

Dopolední plenární část konference zahájil Vladimír Hulík z Odboru školské statistiky, analýz a strategií MŠMT. Ve své přednášce hovořil o vývoji počtu žáků na jednotlivých typech středních škol od roku 1960 do roku 2019 a naznačil i možný trend $v$ prrištích deseti letech s ohledem na demografický vývoj. Zaměřil se přitom na střední odborné vzdělávání, které mělo ve vzdělanostní struktuře obyvatelstva České republiky historicky vždy velmi silné zastoupení. Např́iklad na počátku devadesátých let se studijních oborů s maturitou účastnilo přibližně $55 \%$ ze všech středoškolských žáků. Za pouhých deset let už tento počet stoupl na přibližně 70 \%, a to především vlivem společenských změn na konci roku 1989, kdy bylo ukončeno využívání tvrdých kvót pro přijímání do jednotlivých oborů. V dnešní době se stř̌edního odborného vzdělávání účastní asi $75 \%$ z celkového počtu středoškolských žáků. Strukturu žáků ve středním vzdělávání během prríštích deseti let předpokládají statistici z MŠMT následující: $25 \%$ žáků v učňovských oborech, 50 \% žáků na středních odborných školách a 25 \% žáků na gymnáziích. Očekává se postupný nárůst počtu absolventů gymnázií a následně i růst počtu absolventů vysokých škol. 
Jako druhý vystoupil v plenární části Lajos Somogyvári z University of Pannonia $\mathrm{v}$ mad'arském Veszprému. Ústředním tématem jeho přednášky byly kompetence a proměny požadavků na ně $\mathrm{v}$ čase. $\mathrm{V}$ padesátých letech s rozvojem vědy a techniky začíná růst poptávka po změně kompetencí zaměstnanců. V osmdesátých letech se zejména v západním světě stupňují požadavky na manažerské znalosti a kompetence v oblasti lidských zdrojů. Požadavky na změnu kompetencí se dále měnily a mění v závislosti na sociálních, ekonomických a politických změnách ve společnosti. Změnami kompetencí se zabývá i Evropská unie - Evropská komise ustanovila poradní výbor pro odborné vzdělávání s cílem stanovit vizi „konkurenceschopné a soudržné Evropy“, ve které by systém odborného vzdělávání zohledňoval měnící se požadavky na odborné kompetence.

Změnám v odborném vzdělávání v závislosti na požadavcích současného pracovního trhu se věnovala i Monika Christoph z Univerzity Adama Mickiewicze v Poznani. Hovořila o tom, jak digitalizace pracovního prostředí, globalizace a požadavky na variabilitu vedou k fenoménu digitálních nomádů. U tohoto fenoménu se zdají být klíčovými momenty budování profesního potenciálu, využití kreativity zaměstnanců a hloubková reflexe při současné možnosti vykonávat své povolání z jakéhokoliv místa na světě.

Sonia Wawrzyniak, rovněž z Univerzity Adama Mickiewicze v Poznani, hovořila o aktuální potřebě hledání efektivnějších strategií, jak pracovat se studenty, objevovat jejich potenciál a připravit je tak na jejich budoucí povolání. Prezentovala výsledky projektu „Nadšený student“, který probíhal na polských základních a středních školách v letech 2017-2019 a jehož cílem bylo pomoci žákům a studentům zorientovat se v jejich schopnostech, silných stránkách a předpokladech pro budoucí studium či profesní kariéru.

Po plenární části pokračovala konference ICOLLE jednáním v sekcích, ve kterých vystoupili odborníci s celkem 27 př́spěvky. Jejich zaměření bylo poměrně obsáhlé. Příspěvky se věnovaly např. pracovním schopnostem a životnímu stylu učitelů středních odborných škol, odbornému vzdělávání v ČR a ve vybraných zemích EU, srovnání odborných kompetencí učitelů odborných předmětů ve vybraných zemích EU, kvalitě vysokoškolské výuky, efektivitě online výuky nebo hodnocení pedagogické praxe probíhající v době současné pandemie. Všechny příspěvky, které zazněly na letošním ročníku konference celoživotního vzdělávání ICOLLE, budou zájemcům k dispozici v recenzovaném sborníku příspěvků. 


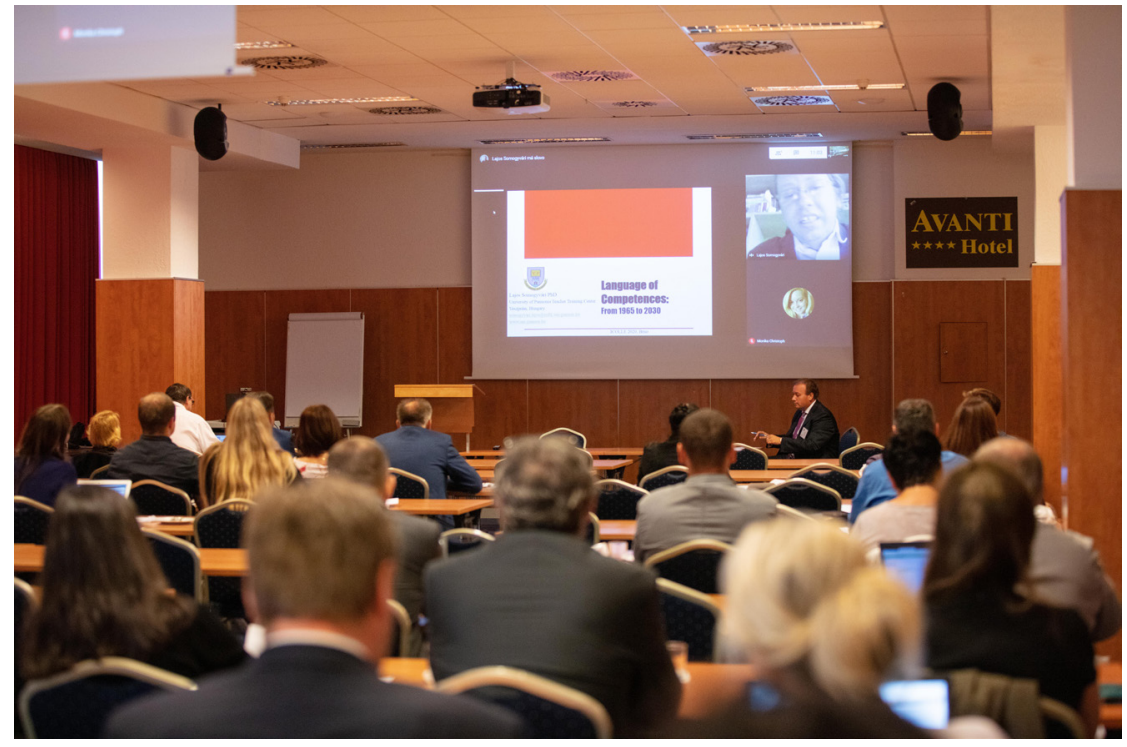

\section{Autor zprávy}

Ing. Martina Urbánková

Mendelova univerzita v Brně, Institut celoživotního vzdělávání, Zemědělská 814/5, 61300 Brno, Česká republika

email: martina.urbankova@mendelu.cz

Přijato: 5. 10. 2020

Link to this article: https://doi.org/10.11118/lifele20201003363 